\title{
Investigating Consistency of a Pro-market Perspective Amongst Conservationists
}

\author{
Libby Blancharda,\#, Chris G. Sandbrook ${ }^{\mathrm{b}}$, Janet A. Fisherc, and Bhaskar Vira ${ }^{\mathrm{a}}$ \\ aDepartment of Geography, University of Cambridge, Cambridge, UK
}

${ }^{b}$ UNEP World Conservation Monitoring Centre, Cambridge, United Kingdom and Department of Geography, University of Cambridge, Cambridge, UK

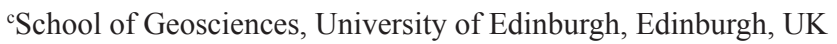

\#Corresponding author. E-mail: libby.blanchard@geog.cam.ac.uk

\begin{abstract}
While biodiversity conservation has had a longstanding relationship with markets, the recent past has seen a proliferation of novel market-based instruments in conservation such as payments for ecosystem services. Whilst a number of conservation organisations have aligned themselves with this 'neoliberal' shift, relatively few studies interrogate the extent to which this move resonates with the values held by conservation professionals. An earlier study of the views of conservationists participating in the 2011 Society for Conservation Biology conference found both supportive and critical perspectives on the use of markets in conservation (Sandbrook et al. 2013b). This paper investigates the consistency of the perspectives identified in the earlier study by applying the same Q methodology survey to a group of Cambridge, UK-based conservationists. While both studies reveal supporting and more sceptical perspectives on the use of markets in conservation, the pro-market perspective in each sample is nearly identical. This finding provides empirical confirmation of a growing body of research that suggests that a relatively consistent set of pro-market perspectives have permeated the thinking of decision makers and staff of conservation organisations. It also lends some support to the suggestion that a transnational conservation elite may be driving this uptake of market approaches.
\end{abstract}

Keywords: biodiversity conservation, markets, commodification, Q methodology, neoliberalism, conservation organisations, values

\section{INTRODUCTION}

Neoliberal conservation and its critics

In the last two decades, the field of biodiversity conservation has increasingly been characterised by the use of market

\begin{tabular}{|l|l|}
\hline \multicolumn{2}{|c|}{ Access this article online } \\
\hline Quick Response Code: & Website: \\
\hline & www.conservationandsociety.org \\
\hline & \\
\hline & \\
\hline
\end{tabular}

logic (Büscher et al. 2012; MacDonald 2010b; Pirard 2012). While so called 'market-based instruments' (MBIs) such as ecotourism, taxation and subsidies have existed in conservation practice for quite some time, new instruments such as payments for ecosystem services (PES), biodiversity derivatives and offsets, and mitigation banking have recently become more widespread (Arsel and Büscher 2012; Landell-Mills and Porras 2002; Pattanayak et al. 2010). MBIs can be defined as mechanisms that attribute a price to nature (Pirard 2012), though their links to true markets are sometimes questionable (Muradian et al. 2013; Pirard 2012). MBIs are increasingly used in conservation because there is an expectation that they will deliver: efficiency through the use of the market to internalise externalities (Brockington and Duffy 2011); an economic rationale for conservation that decision-makers

Copyright: (C) Blanchard et al. 2016. This is an open access article distributed under the terms of the Creative Commons Attribution License, which permits unrestricted use and distribution of the article, provided the original work is cited. Published by Wolters Kluwer - Medknow, Mumbai | Managed by the Ashoka Trust for Research in Ecology and the Environment (ATREE), Bangalore. For reprints contact: reprints@medknow.com 
understand (Daily 1997; Pearce and Barbier 2000); new funding sources (Balmford and Whitten 2003; Ferraro 2001; Wunder 2007); and potential "win-wins" by addressing both biodiversity conservation and poverty alleviation (Pagiola et al. 2005).

Market-based conservation practice has resulted in new and altered relationships between conservation organisations, the public and private sectors, and local people (Sandbrook et al. 2013b). Mainstream environmental policy initiatives, such as 'The Economics of Ecosystems and Biodiversity' (TEEB) study (TEEB 2010), the UN Environment Programme's 'Towards a Green Economy' report (UNEP 2011), the Convention on Biological Diversity's 'Strategic Plan for Biodiversity' 2011-2020 (CBD 2010), the EU Biodiversity Strategy to 2020 (European Commission 2011) and the UK's Natural Capital Committee (www.naturalcapitalcommittee. org) all promote the use of market-based instruments to conserve and manage nature. Many biodiversity conservation organisations have increasingly promoted the use of markets and have formed partnerships with private sector actors (Igoe and Brockington 2007; MacDonald 2010b). These practices represent a departure from conservation norms that were prevalent up until around two decades ago, when mainstream conservation organisations were more likely to embrace "values, approaches and missions that were deeply incompatible" with private sector interests (MacDonald 2010b: 515) and to espouse alternative perspectives challenging neoliberal capitalism (Harvey 2003).

This neoliberal turn in conservation and the presumed win-win claims advanced by such perspectives have been the subject of criticism from within the social science community (Arsel and Büscher 2012; Igoe and Brockington 2007). Neoliberal conservation is defined as an "amalgamation of ideology and techniques informed by the premise that natures can only be 'saved' through their submission to capital and its subsequent revaluation in capitalist terms" (Büscher et al. 2012: 4). Such scholars see this trend as part of the wider political economic process of neoliberalisation (Castree 2008; Igoe and Brockington 2007; McCarthy and Prudham 2004), the expansion of markets into increasingly broad areas of society over the last few decades (Sandel 2012). Given that neoliberal conservation "privileges as a solution the very structures and processes of neoliberal capitalism that produce the socio-ecological damages it seeks to redress" (Büscher et al. 2012: 14), critical social scientists question whether capitalist market mechanisms can resolve environmental problems (Igoe and Brockington 2007; Storm 2009).

Specifically, critical social scientists interrogate the process by which neoliberal conservation commodifies nature and question the outcomes of this process, which some have dubbed "Nature TM Inc."(Arsel and Büscher 2012). Castree (2008) argues that neoliberalism does not so much entail deregulation as require reregulation to reduce complex ecosystems into tradable commodities. This commodification process creates new types of value (Arsel and Büscher 2012) and facilitates new avenues for capital accumulation (Harvey 2006; Schurman and Kelso 2003). In addition to the moral critique of whether nature should be reduced to tradable commodities, scholars question the outcomes of this commodification process, which can result in privatisation (Heynen and Robbins 2005), social and economic displacement or exclusion (Brockington 2002) and the potential for elite-capture of newly available benefits (Igoe and Brockington 2007). Further, McAfee (2012) argues that while much attention has been focused on the technical and institutional obstacles to implementing market-based approaches to conservation, this has detracted from the ways in which winners and losers are actively produced through the exchange process of markets. Indeed, the act of trading itself has significant redistributionary consequences (Vira 2002). Thus, scholars argue that instead of creating synergistic growth and win-wins, the neoliberalisation of nature could result in winners and losers and potentially a reduction in biodiversity conservation effectiveness (Vira 2015).

\section{The circulation of ideas within epistemic communities}

The critiques advanced by social scientists regarding neoliberal conservation seem to have had little impact on conservation professionals or decision makers. Büscher et al. (2012) observe that neoliberal solutions amongst conservationists seem to be the result of a consensus and seem not to be subjected to internal dissent. They propose that this lack of dissent is because neoliberal conservation functions as an ideology that has become socially (and ecologically) embedded through the generation of hegemonic governance structures and practices (Büscher et al. 2012). They write: "as an ideology it needs to be believed in; its central tenets should not be questioned" (Büscher et al. 2012: 15). Thus, they propose that critical perspectives, when voiced amongst conservation professionals, are not just ignored but actively suppressed or 'muted' in various ways, including through "the disciplining force of denial or disregard" (Büscher et al. 2012: 21).

Peck (2011) calls such a phenomenon where various forms of evidence are ignored and policies reflect the strategies of those with particular interests, the result of 'fast policy.' He notes that in such contexts, what appears to be pragmatic policy learning is in fact policy replication operating within specific ideological parameters, with a 'push' toward particular solutions amongst policy entrepreneurs and decision makers (Peck and Theodore 2010b). Peck and Theodore (2010b) write that: "there can be no doubt that canalized forms of transnational policy learning... embedded within tight ideological parameters - are playing heightened roles in animating" various policy landscapes (Peck and Theodore 2010b: 206).

The trend towards market-based practice in biodiversity conservation could be the result of shifting perspectives amongst conservationists as a 'community of practice', led by a similarly tight set of key decision makers. A community of practice (Lave and Wenger 1991; Wenger 2000) is defined as a "collection of people who engage on an ongoing basis in some common endeavor" (Eckert 2006: 683) and who share practices reflecting their collective learning (Eckert 2006; 
Wenger 2000). As a result, they develop shared ways of addressing recurring problems. But how do collective strategies within a community of practice shift and evolve? Who drives and decides what types of knowledge and tools are embraced or rejected within a community? Wenger (2000) and Peck and Theodore (2010b) refer to this process as an 'alignment' that coordinates perspectives, interpretations, and action. Indeed, Peck and Theodore argue that such alignment comes from dense expert networks and epistemic communities of practice that "serve and sustain" policies (Peck and Theodore 2010b: 207). Haas (1992) corroborates this link between alignment and epistemic communities, which he defines as "networks of knowledge-based experts" (Haas 1992: 2) who play key roles in articulating and framing problems and potential solutions within their particular communities. According to Haas (1992), such communities defer to these 'knowledge elites' who shape strategies and thinking within the community, resulting in the community of practice learning new patterns of reasoning and behavior.

The propagation of ideas within epistemic communities usually involves close personal connections, shared ideologies and repeated interaction in a variety of settings. As such, international conference meetings and the geographic co-location of professionals are both examples of settings where such propagation and alignment of ideas could occur. Indeed, MacDonald (2010) argues that high profile meetings within the biodiversity conservation community provide important 'fields' for social and cultural reproduction, in other words "moments when conservationists come together as a tangible (as opposed to imaginary) global community to reaffirm their values and beliefs" (Büscher et al. 2012: 18); this is also the case with geographic co-location.

Examined through the lens of this scholarship, one explanation for the increasing dominance of market-based interventions in conservation could be the emergence of an epistemic community, actively promoting the adoption of such approaches during the last two decades. Holmes (2011) suggests that such a community, a 'transnational conservation elite' that shares, replicates, amplifies, and promotes ideas about market-based solutions to the conservation community is emergent, but Holmes does not provide empirical evidence indicating the existence of such a transnational conservation elite.

\section{METHODS}

This paper uses Q methodology to empirically investigate perspectives on the role of markets in conservation amongst members of two distinct, but potentially overlapping, conservation communities. It does so by comparing the results of an earlier Q study conducted with delegates at the International Congress for Conservation Biology (ICCB) in Auckland, New Zealand in December 2011 (hereafter referred to as 'the ICCB study') (Sandbrook et al. 2013b) with new data collected using the same Q methodology instrument with staff of conservation organisations based in and around Cambridge, UK (hereafter referred to as 'the Cambridge study').

For this comparative study, we conducted semi-structured interviews using $Q$ methodology. Q methodology has increasingly been used in the field of social science research on conservation (Sandbrook et al. 2013a) to study conservationists' subjective values and perspectives (Mazur and Asah 2013; Rastogi et al. 2013; Sandbrook et al. 2013b), as well as being increasingly used in environmental research (e.g. Brannstrom 2011; López-i-Gelats et al. 2009; Robbins 2000, 2006). We used the same Q methodology survey as the Sandbrook et al (2013b) ICCB study, with 17 conservation professionals working for conservation organisations located in and around Cambridge, UK, in February and March 2013. We then conducted a direct comparison of the perspectives represented in both the ICCB and Cambridge datasets.

The city of Cambridge has one of the largest clusters of biodiversity conservation organisations and researchers in the world ${ }^{1}$, many of which are linked through the Cambridge Conservation Forum $(\mathrm{CCF})^{2}$, the Cambridge Conservation Initiative $(\mathrm{CCI})^{3}$, and the University of Cambridge Conservation Research Institute (UCCRI) ${ }^{4}$. Many staff of CCI member organisations are now housed together in a new campus building that serves as the hub for CCI (Stokstad 2016). This research included, but was not limited to, conservation professionals who were employees of conservation organisation partners of the Cambridge Conservation Initiative and affiliated with the University of Cambridge Conservation Research Institute.

The organisations whose employees took part in the interviews represent the various types, sizes and focuses of conservation organisations that exist in Cambridge. The Cambridge conservation community is made up of global intergovernmental organisations such as the United Nations Environment Programme World Conservation Monitoring Centre, the International Union for the Conservation of Nature, and the International Whaling Commission; internationally focused, large biodiversity conservation organisations and networks such as Flora and Fauna International and Birdlife International; and much smaller conservation NGOs with a more limited remit and geographical focus. The larger conservation organisations in Cambridge have over 200 employees in their organisational headquarters, with partners and networks across more than 100-150 countries (and annual operational budgets of the order of \$40-50 million), while those at the other end may have less than five employees and correspondingly smaller budgets. Many employees have Masters degrees (or equivalent) or PhDs. The Cambridge organisations represent what might be thought of as 'mainstream' conservation practice, and do not include any organisations associated with radical opposition to market-based conservation. Many individuals from the Cambridge conservation community (typically those who are more senior members of larger conservation organisations) interact with other members of the global conservation community through participation in 
conferences, knowledge platforms and global convention meetings and through employment mobility. However, the Cambridge conservation community also includes networks and initiatives, developed over approximately the last 15 years that are designed to facilitate frequent interactions between conservation professionals, conservation science researchers and critical social scientists. Therefore, Cambridge-based conservation professionals and scientists might be more exposed to critical thinking on markets and conservation than might be the norm in other contexts. Our research, therefore, sheds some light on whether this slightly unusual cluster of individuals and organisations reproduces or departs from the patterns observed at a gathering of conservation professionals at ICCB 2011.

\section{Q Methodology}

To undertake this research, we used Q methodology, a method used to quantitatively study respondent's subjectivity and firstperson viewpoints (Watts and Stenner 2012). Q methodology is used to statistically measure the extent to which opinions and viewpoints are shared between respondents (Watts and Stenner 2012). It combines the qualitative study of perceptions with statistical analysis, revealing key qualitative viewpoints and allowing them to be understood at a high level of quantitative detail (Watts and Stenner 2012). It is designed to support the identification and disaggregation of "currently predominant social viewpoints and knowledge structures relative to a chosen subject matter" among a relatively small group of respondents (Watts and Stenner 2012: 42). Thus, Q methodology "supports an understanding of the detailed composition of positions, making it suitable ... to understand the perspectives of conservation professionals" (Sandbrook et al. 2013b: 235).

Q methodology begins by requiring respondents to arrange statements drawn from a literature review of the subject onto a grid (shown in Figure 1). These statements are known as the Q set. We used the same 34 statement Q set developed and used in the ICCB study to enable comparison between the Cambridge and the ICCB data (Table 1). This Q set was originally developed by Sandbrook et al (2013b) using a literature review and the authors' extensive interactions with conservation practitioners and organisations. It was designed to include statements across a continuum of perspectives on market-based approaches to conservation, and was piloted with two respondents to ensure a balanced sample of statements across a range of perspectives (Sandbrook et al. 2013b). The Q set of statements included statements of "ethics, pragmatism, ideology and local impacts" as well as a range of perspectives on market-based conservation (Sandbrook et al. 2013b: 11). To be appropriate for a Q study the statements in the Q set should be familiar to all respondents and cover the range of views present within the respondent community. ${ }^{5}$ Based on our knowledge of the Cambridge conservation community we felt that the statements developed for the ICCB study met this criterion.

\section{Participants}

Our Q survey was conducted with employees of conservation organisations located in and around the city of Cambridge. Participants included both, those who worked for large international conservation organisations and smaller, more locally focused conservation organisations. All the organisations from which staff members were interviewed were involved to some extent in market-based conservation activities. While the majority of participants were senior employees at the top of their organisational hierarchies, two respondents were mid-career professionals. Eleven were male and six were female. All but two participants were citizens of OECD countries.

\section{Data Collection: The Interview}

Data was collected from semi-structured, face-to-face interviews with participants in quiet locations away from other people. At the start of the interview, participants were promised anonymity and asked to share their own personal views, as opposed to the views of their organisation. After briefly explaining the project and Q methodology, respondents were asked to complete the Q survey, in which they sorted the set of 34 printed statements onto a standard distribution grid (see Figure 1). Participants sorted statements over a relative range, from "strongly disagree" (-4) on one side of the grid to "strongly agree" $(+4)$ on the other (see Figure 1).

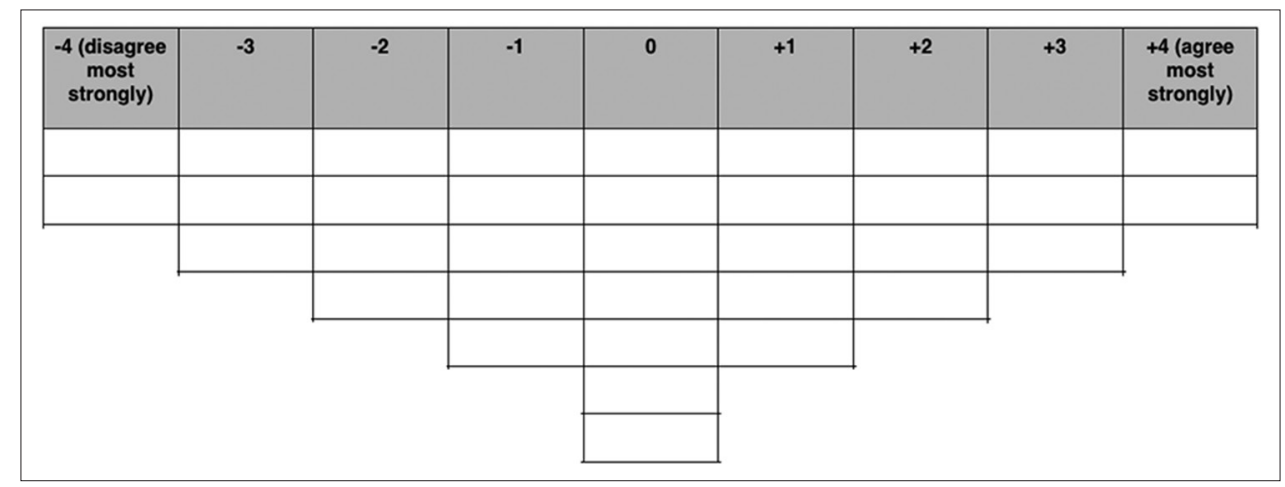

Figure 1

Design of the Q methodology grid used 
116 / Blanchard et al.

Table 1

Factor comparison between the Cambridge and ICCB studies

\begin{tabular}{|c|c|c|c|c|c|c|c|c|c|c|}
\hline \multirow[b]{2}{*}{ Statement } & \multicolumn{2}{|c|}{$\begin{array}{l}\text { Cambridge } \\
\text { factor } 1\end{array}$} & \multicolumn{2}{|c|}{$\begin{array}{c}\text { ICCB } \\
\text { factor } 1\end{array}$} & \multicolumn{2}{|c|}{$\begin{array}{l}\text { Cambridge } \\
\text { factor } 2\end{array}$} & \multicolumn{2}{|c|}{$\begin{array}{c}\text { ICCB } \\
\text { factor } 2\end{array}$} & \multicolumn{2}{|c|}{$\begin{array}{l}\text { Cambridge } \\
\text { factor } 3\end{array}$} \\
\hline & Z-Score & Ranking & Z-Score & Ranking & Z-Score & Ranking & Z-Score & Ranking & Z-Score & Ranking \\
\hline 1 Markets provide a new source of funding & 0.855 & 2 & 1.512 & 3 & 1.139 & 2 & 0.686 & -1 & 0.428 & 1 \\
\hline 2 Markets provide a large source of funding & 0.689 & 1 & 0.889 & 2 & -0.831 & -2 & -0.45 & -1 & -0.391 & -1 \\
\hline 3 Markets provide a sustainable source of funding & 0.684 & 1 & 0.785 & 1 & -0.891 & -3 & -0.387 & -1 & -0.848 & -2 \\
\hline 4 Sufficient funds without turning to markets & -1.434 & -3 & -1.055 & -3 & -0.791 & -2 & -0.25 & -1 & 0.305 & 1 \\
\hline 5 Markets most efficient for allocating resources & -0.483 & -1 & -0.148 & 0 & -0.91 & -3 & -1.214 & -2 & 0.239 & 1 \\
\hline 6 Markets preferable as conditional on performance & -0.125 & 0 & 0.138 & 0 & -0.577 & -1 & -0.448 & -1 & -1.116 & -3 \\
\hline $\begin{array}{l}7 \text { Markets most effective when directly linked to } \\
\text { conservation }\end{array}$ & 1.081 & 3 & 1.541 & 4 & 1.527 & 3 & 1.304 & 3 & -0.289 & -1 \\
\hline $\begin{array}{l}8 \text { Conservation should embrace market, not fight } \\
\text { against it }\end{array}$ & 0.885 & 2 & 0.508 & 1 & -0.295 & 0 & -1.017 & -2 & -0.189 & -1 \\
\hline $\begin{array}{l}9 \text { Biodiversity loss primarily driven by market } \\
\text { capitalism }\end{array}$ & 0.823 & 2 & 0.083 & 0 & 1.59 & 3 & 1.003 & 3 & -0.441 & -1 \\
\hline $\begin{array}{l}10 \text { Bio-D that can't survive in marketplace not worth } \\
\text { conserving }\end{array}$ & -2.242 & -4 & -2.011 & -4 & -2.058 & -4 & -2.157 & -4 & -2.174 & -4 \\
\hline $\begin{array}{l}11 \text { Markets too unpredictable for conservation } \\
\text { purposes }\end{array}$ & -0.208 & -1 & -0.8 & -2 & 0.719 & 2 & 0.758 & 2 & 0.318 & 1 \\
\hline 12 Pragmatism not good reason to risk markets & -0.447 & -1 & -0.714 & -1 & -0.699 & -1 & 0.828 & 2 & -0.667 & -2 \\
\hline 13 Decision makers understand monetary values & 0.931 & 3 & 0.878 & 1 & -0.496 & -1 & -1 & -2 & 1.202 & 3 \\
\hline 14 Opponents of markets not living in the real world & 0.808 & 1 & -0.998 & -2 & -0.319 & 0 & -1.518 & -3 & -0.037 & 0 \\
\hline 15 Private sector partnership undermines conservation & -1.859 & -4 & -1.518 & -3 & -0.865 & -2 & 0.492 & 1 & -1.622 & -3 \\
\hline 16 No difference between commodity and ES markets & -1.201 & -3 & -0.97 & -2 & -1.202 & -3 & -0.775 & -2 & -1.355 & -3 \\
\hline 17 Market restructuring can't deliver conservation & -1.2 & -3 & -1.159 & -3 & 0.468 & 1 & 0.708 & 2 & -0.152 & 0 \\
\hline 18 Nothing really new about market-based approach & -0.314 & -1 & -0.583 & -1 & -0.752 & -2 & -0.058 & 0 & 0.449 & 2 \\
\hline $\begin{array}{l}19 \text { By engaging in markets, actors find beneficial } \\
\text { outcomes }\end{array}$ & 0.796 & 1 & 1.039 & 2 & 0.219 & 1 & 0.232 & 0 & 0.811 & 2 \\
\hline $\begin{array}{l}20 \text { Cons. market expansion nothing to do with } \\
\text { neoliberalism }\end{array}$ & -0.191 & 0 & -0.176 & 0 & -0.75 & -1 & -0.701 & -1 & \begin{tabular}{|l|}
-0.189 \\
\end{tabular} & 0 \\
\hline $\begin{array}{l}21 \text { Cons. orgs should promote the economic valuation } \\
\text { of nature }\end{array}$ & 0.601 & 1 & 1.084 & 2 & -0.667 & -1 & -1.425 & -3 & 0 & 0 \\
\hline $\begin{array}{l}22 \text { Cons. orgs shouldn't support the commodification } \\
\text { of nature }\end{array}$ & -1.036 & -2 & -0.964 & -2 & 0.158 & 0 & 1.482 & 4 & -0.173 & 0 \\
\hline $\begin{array}{l}23 \text { Markets can't handle unpredictable properties of } \\
\text { ecosystems }\end{array}$ & 0.107 & 0 & -0.428 & -1 & 1.156 & 2 & 1.4 & 3 & 1.268 & 3 \\
\hline $\begin{array}{l}24 \text { Need more evidence on the impacts of market } \\
\text { conservation }\end{array}$ & 0.369 & 0 & 0.775 & 1 & 1.692 & 4 & 0.556 & 1 & -0.515 & -2 \\
\hline $\begin{array}{l}25 \text { Putting a price on nature doesn't detract from } \\
\text { other values }\end{array}$ & 1.856 & 4 & 1.265 & 3 & -0.345 & 0 & -1.519 & -4 & 0.231 & 0 \\
\hline $\begin{array}{l}26 \text { Cons. choices ethical and political, not solely } \\
\text { economic }\end{array}$ & 1.45 & 4 & 1.554 & 4 & 2.144 & 4 & 1.874 & 4 & 1.103 & 2 \\
\hline $\begin{array}{l}27 \text { Artificial substitutes may be more competitive than } \\
\text { nature }\end{array}$ & 0.516 & 0 & 0.155 & 0 & 1.218 & 3 & 0.225 & 0 & 1.898 & 4 \\
\hline $\begin{array}{l}28 \text { Markets have negative impacts where limited exp. } \\
\text { of them }\end{array}$ & -0.107 & 0 & 0.158 & 1 & 0.465 & 1 & 0.43 & 1 & 1.173 & 2 \\
\hline $\begin{array}{l}29 \text { Market cons. increases inequality in local } \\
\text { communities }\end{array}$ & -0.517 & -1 & 0.104 & 0 & 0.753 & 2 & 0.426 & 0 & 0.297 & 1 \\
\hline $\begin{array}{l}30 \text { Market transactions are voluntary, so can't be } \\
\text { exploitation }\end{array}$ & -0.926 & -2 & -1.532 & -4 & -1.425 & -4 & -1.287 & -3 & -1.783 & -4 \\
\hline $\begin{array}{l}31 \text { Markets provide livelihood opportunities for the } \\
\text { poor }\end{array}$ & 0.878 & 2 & 0.908 & 2 & 0.394 & 1 & 0.2 & 0 & 1.326 & 3 \\
\hline $\begin{array}{l}32 \text { Markets deny poor people access to natural } \\
\text { resources }\end{array}$ & -0.857 & -2 & -0.709 & -1 & -0.13 & 0 & 0.553 & 1 & -0.906 & -2 \\
\hline 33 Market cons. creates local conservation incentives & 1.014 & 3 & 1.143 & 3 & 0.619 & 1 & 0.134 & 0 & 2.022 & 4 \\
\hline $\begin{array}{l}34 \text { Private sector partners. constrain criticism of } \\
\text { markets }\end{array}$ & -1.198 & -2 & -0.755 & 1 & -0.26 & 0 & 0.916 & 2 & -0.223 & -1 \\
\hline
\end{tabular}

This distribution grid required respondents to rank statements relative to other statements, illuminating which statements they believed were most important. Statements were shuffled, so that they were presented in a different order to each respondent. 
As the sorting took place, respondents were encouraged to explain their rationale for their choices of placement for each statement. In cases where respondents had questions about a statement, a limited explanation of the statement's meaning was given in a way that sought not to introduce bias. After the survey was finished, respondents were asked to explain their reasoning behind statements they chose for the two extremes and for the statements in the middle of the distribution grid. This qualitative data helped in understanding the meaning and significance of participants' choices beyond each participant's sort. We took notes during the interviews as respondents explained their decisions for ranking particular statements, including verbatim quotes for the qualitative component of the data collection. These statements and quotes were then used to interpret and corroborate the results.

While participants were encouraged to follow the normal distribution of the grid, eight participants did not arrange their grid like this. While having participants respond within the normal distribution is a practical way of encouraging them to prioritise statements relative to others, it is not essential for use of the method, as even unequally distributed statements reveal their relative level of agreement about each statement in relationship to the others (Brown 1980; Watts and Stenner 2012).

\section{Q Data Analysis}

The results of the Q survey, called Q sorts, were input into the PQMethod Software, which is specifically designed for $\mathrm{Q}$ methodological analysis. The software analysis requires three statistical steps: correlation, factor analysis and standard factor score computation (Watts and Stenner 2012). Correlation measures the degree of agreement between any two Q sorts and denotes their similarity in a correlation matrix. Factor analysis then searches for patterns of association between the measured variables in the matrix, and reduces them into a small number of highly correlated viewpoints, called 'factors' (Watts and Stenner 2012). These factors then undergo 'rotation,' which refers to the software plotting identified factors on a three-dimensional correlation matrix and rotating (e.g. moving or adjusting) the matrix to identify and eliminate sorts that are significantly associated onto more than one factor and therefore distinctly define no factor. This analysis results in each factor identifying a subset of respondents within a Q study who rank-ordered the statements in a similar way, displaying similar perspectives about the provided statements.

For the Cambridge study, we used the software to rotate two, three, and four factors and looked at the results. We ultimately decided to use and interpret the three factor result, using two common decision making criteria (Watts and Stenner 2012). First, we applied the Kaiser-Guttman criterion, which states that the Eigenvalue of a factor should be greater or equal to 1.00 (Watts and Stenner 2012). Second, we accepted Factors One, Two, and Three because they were the only factors that had two or more Q sorts that loaded significantly upon each, a common criterion for factor selection (Watts and Stenner 2012).
During the rotation process, the PQMethod 'flags' specific $\mathrm{Q}$ sorts that are representative of particular factors. It then generates a 'typical' Q sort, which represents an ideal-type composite version of all Q sorts flagged for that factor. Data interpretation is then done by examining these ideal-type $\mathrm{Q}$ sorts alongside the qualitative data. While not all Q studies include qualitative data, doing so allows for richer interpretation of the results and confirmation that the factor interpretation fits the views expressed by respondents during their interview. Narrative descriptions are then written in order to explain the perspectives defined by each factor. These descriptions, supported by direct quotations from respondents, are presented as results. It should be noted that the interpretation of $Q$ results is a somewhat subjective process (Eden et al. 2005) and comparing factors between Q studies is still experimental, though some published studies have done so (e.g. Tuler and Webler 2009). We chose to do a direct, side-by-side comparison of the idealised factors of both the ICCB and Cambridge datasets to identify points of similarity and difference.

\section{RESULTS}

\section{Points of consensus amongst all factors from both studies}

All respondents from both the ICCB and Cambridge studies held a limited set of core beliefs, as evidenced by their similar ranking of five statements in the ideal-type sorts, suggesting a common recognition of some limitations of markets as conservation tools in both theory and practice (Table 1). They collectively believed that biodiversity is worth conserving for its multiple values (statement 10), and that conservation choices are ethical and political, not solely economic (statement 26). Respondents from both studies recognised a fundamental difference between markets for traditional commodities and markets for ecosystem services (statement 16). They also recognised the potential for adverse consequences in the use of markets in conservation, including the possibility for exploitation (statement 30 ).

There was one statement that respondents from both studies did not express a strong opinion on, with relatively neutral responses. This statement was: "the expansion of market-based conservation has nothing to do with neoliberalism" (statement 20). The majority of Cambridge respondents (16 out of 17) asked (during their $Q$ sort interview) for a definition of neoliberalism when they encountered this statement. Sandbrook et al. also noted in their ICCB study that there was a lack of familiarity among their respondents with this term (Sandbrook et al. 2013b) ${ }^{6}$. When asked, interviewers from both studies provided participants with a general definition of neoliberalism that sought not to introduce a bias, but, given respondents' relative unfamiliarity with the term, it is not surprising that this statement did not attract strong views. Indeed, it is interesting to note that the lack of recognition of this term, which is fairly dominant in the critical literature on markets and conservation, does lend weight to the argument 
that mainstream conservation practitioners and researchers are not engaging with these critiques (Sandbrook et al. 2013a). This raises the question of how to engage practicing conservationists with the latest critical social science literature on conservation, and how social scientists can better communicate and disseminate their research to conservation professionals.

\section{Factor One: stability across both studies}

There was a high level of similarity between Factor One in each study. Respondents associated with this factor expressed support and enthusiasm for the use of marketbased interventions in conservation. In comparing Factor One between the two studies, 13 statements were ranked exactly the same on the distributional grid, 17 statements were ranked within one integer of difference, and only four statements (out of a total of 34) were ranked by more than one integer of difference (see Table 1). Seven of the 12 respondents from the ICCB study were associated with Factor One, including two senior employees of large international conservation organisations, one government advisor and four academics, of whom two were conservation scientists and two were economists. Likewise, seven of the 17 respondents from the Cambridge study were associated with Factor One, including four senior employees from large international conservation organisations, a senior employee from a mid-sized international conservation organisation, a senior employee of a local conservation organisation, and a senior employee of a national conservation organisation.

The collective group of respondents that were associated with Factor One were the least sceptical of any group about potential negative effects of markets in conservation. In terms of impacts on local people, respondents associated with Factor One saw little downside in engaging with market-based conservation. They disagreed that market-based conservation denies poor people access to natural resources (statement 32 ) and with the notion that market-based conservation increases inequality (statement 29). Instead, they saw potential for market-based conservation to create local incentives to support conservation (statement 33) and provide livelihood opportunities for the poor (statement 31). In terms of conservation outcomes, respondents associated with Factor One were indifferent to the idea that "there is a risk that in a market, artificial substitutes may become more competitive than nature at providing services" (statement 27). They were somewhat indifferent to the statement: "markets have no way of dealing with unpredictable properties of ecosystems, and this makes them dangerous for conservation" (statement 23) and strongly disagreed with the idea that "conservation partnerships with the private sector are undermining conservation outcomes" (statement 15). This group saw little downside in turning to markets. Unlike respondents from other factors, respondents associated with Factor One disagreed with the notion that markets are too unpredictable to be used for conservation (statement 11). More strongly than respondents associated with other factors, these respondents believed that "putting a price on nature does not detract from all the other reasons to value it" (statement 25).

Respondents associated with Factor One in both studies saw the use of markets in conservation as a realistic and necessary tool. They distinctively believed that markets provide both a large (statement 2) and sustainable (statement 3) source of funding for conservation, and strongly believed that sufficient funding to reverse biodiversity loss could not be raised through any other method other than markets (statement 4). Respondents associated with this factor held a strong belief that markets can be restructured sufficiently to deliver conservation outcomes (statement 17), and saw markets as potentially helpful in delivering conservation outcomes. They were also the only group to agree with the statement: "conservationists should embrace market-based capitalism, not fight against it" (statement 8) and the statement: "conservation organisations should promote the economic valuation of nature" (statement 21). Respondent $22^{7}$ (from the Cambridge study) saw the framing of biodiversity in economic terms as beneficial, explaining, "the conservation community has struggled to express the value of ecosystems. And what we're seeing is that the economic camp is helping lead us into another way of valuing nature." Respondent 15 said, "if we turn our back on monetising nature, we are missing a huge opportunity to embed conservation into our society." Likewise, Respondent 28 said, "we used to be combative and confrontational, presenting to the rest of the world capitalism as the cause of the decline in biodiversity. Now we are moving into a much more mature frame of mind that says collaboration. Let's try to solve these problems together. Let's take what money, wealth, and capitalism can do at face value and help it do the right thing to make the world a better place."

Only four statements from the comparative Factor One sorts were ranked with more than one integer of difference. The Cambridge Factor One respondents agreed more strongly with the statements: "biodiversity loss is primarily driven by market-based capitalism" (statement 9: Cambridge study +2 , ICCB 0 ) and "decision makers understand monetary values, so conservation should be framed in these terms" (statement 13: Cambridge study +3 , ICCB +1 ). In the case of the statement: "market-based conservation transactions are voluntary, so there is no possibility for exploitation" the ICCB study participants disagreed more strongly (statement 30: Cambridge study -2, ICCB -4).

The largest amount of disparity between Factor One respondents from the two studies was their ranking of the statement: "Those who oppose market-based conservation are not living in the real world" (statement 14: Cambridge study +1 , ICCB -2). This statement was met with verbal scepticism by many of the respondents, some of whom questioned the validity of such a statement in a research setting, despite being reminded that $\mathrm{Q}$ methodological research is based on understanding subjective opinions. We felt the statement was perhaps too ambiguous for participants to interpret (many said: "it depends what you mean by the real world"), which may have been the reason for such a disparity in ranking of 
this particular statement between the Factor One-associated respondents from the two studies.

\section{Various sceptical perspectives within remaining Factors}

The level of stability between the Factor One idealised sorts was not seen when comparing the remaining factors of the ICCB and Cambridge studies. While the remaining factors were distinguished from Factor One on several key points, each portrayed differently nuanced variations of caution and scepticism towards the use of markets in conservation.

Collectively, respondents associated with the remaining factors were not swayed by the rationale that markets provide large (statement 2) or sustainable (statement 3) sources of funding for conservation. Instead, they rejected this funding rationale. Respondent 26 (Cambridge Factor Two) said, "I don't think that markets are providing a large source of funding for the right kinds of conservation ... and the jury is still out on whether markets provide a sustainable source of funding. Sufficient funding hasn't happened so far [for conservation], so why should it now?" Respondent 14 corroborated this point, "no evidence will support that markets provide a sustainable source of funding for conservation. We are miles away from that." Those associated with the remaining factors differed from Factor One in that they gave a positive ranking for the statement: "Markets are too unpredictable to be used for conservation purposes" (statement 11). These respondents felt that because markets have no way of dealing with unpredictable properties of ecosystems, it makes them dangerous for conservation (statement 23), while respondents associated with Factor One from both studies were rather indifferent to this concern. Respondent 23 (Cambridge Factor Three) explained: "We tend to place values on ecosystems and species based on what is predictable. But we know that a lot of ecosystem processes can be unpredictable. Markets cannot handle things that are unpredictable. We cannot totally depend on markets, because we need mechanisms for dealing with surprises."

Beyond these points of collective disagreement with Factor One, the remaining positions remained unique in character across both studies. Each expressed a different, nuanced perspective of caution and scepticism towards the use of markets in conservation. Sandbrook et al. defined the ICCB study's Factor Two as having "ideological scepticism of the underlying rationale for market-based conservation" (Sandbrook et al. 2013b). Details of Factors Two and Three in the Cambridge study are given below.

\section{Cambridge Factor Two - Evidence Oriented Market Sceptics}

Respondents associated with the Cambridge study's Factor Two were sceptical of markets in conservation based on a perceived need for more evidence. Six respondents were flagged for the Cambridge Factor Two. This group included two senior employees from a large international conservation organisation, a senior and mid-level respondent from two large international conservation organisations, one senior respondent from a national conservation organisation, and a senior employee of a small international conservation organisation.

Respondents associated with the Cambridge Factor Two believed strongly and distinctly that "more evidence is needed on the impacts of market-based conservation before we go too far" (statement 24). Respondent 26 explained, "a lot of people are announcing that partnerships with the private sector are the way forward in conservation, but there is not a lot of evidence behind it." Respondents strongly agreed that "biodiversity loss is primarily driven by market-based capitalism" (statement 9) and were sceptical that markets could be restructured sufficiently to deliver conservation outcomes (statement 17) They worried about the unpredictability of markets (statement 11) and were concerned that "there is a risk that in a market, artificial substitutes may become more competitive than nature at providing services" (statement 27).

Like the ICCB Factor Two, those associated with the Cambridge Factor Two disagreed somewhat with the rationale that "decision makers understand monetary values, so conservation should be framed in those terms" (statement 13). Instead, respondents felt that decision makers understand more than just economic arguments, and that conservationists do not necessarily have to cater to economic rationales for their arguments to be recognised. Respondent 16 said, "I don't think it's true that decision makers are only moved by the economic argument. Decision makers are moved by all sorts of reasons. It's a myth that they are only swayed by markets." Respondents did not think efficiency was a good reason to engage with markets in conservation (statement 5). Respondent 16 said: "I don't think the concept of efficiency applies to biodiversity."

\section{Cambridge Factor Three - Social Outcome Focused Realists}

The ICCB study yielded two factors, while the Cambridge study yielded three factors. Respondents associated with Cambridge Factor Three saw the potential for the use of markets in conservation to benefit local people, but were sceptical about the ability of markets to deliver biodiversity conservation outcomes. Three respondents were associated with this factor, including a senior employee of a small international conservation organisation, a senior employee of a small national conservation organisation, and a mid-level employee of a large international conservation organisation (whose senior employees interviewed were flagged to either Factor One or Factor Two). When we ran a two-factor solution for the Cambridge study and compared it to the final three-factor solution, one of these respondents was flagged for Factor One in the two-factor solution, while the two other respondents were flagged for Factor Two in a two-factor solution. This suggests that Factor Three is constituted of a hybrid of viewpoints from both Factors One and Two from the Cambridge study. Indeed, Factor Three reveals a pragmatism for using markets that was reflected in both the ICCB and 
Cambridge studies' Factor One, alongside a scepticism towards the ability of markets to deliver certain outcomes, which was reflected in the Cambridge Factor Two.

Respondents associated with Factor Three saw utility in using market-based conservation to create incentives for local people (statement 33), and believed that "market-based conservation provides livelihood opportunities for the rural poor" (statement 31). While respondents associated with this factor saw the potential of markets to deliver positive social outcomes, they recognised that social outcomes are context specific and dependent on how market-based conservation initiatives are implemented. For example, unlike Factor One respondents, these respondents saw the possibility of markets having negative social impacts in places with limited experience of the market economy (statement 28). They also believed that even though market-based conservation is voluntary, this does not negate the possibility for it to be exploitive (statement 30). Respondent 19 said, "markets could go both ways. [They] could increase or decrease inequality." Respondent 23 agreed, "for a market to operate successfully, all actors need access to all information. Unfortunately, many people in local communities have limited information. If this is the case, if you introduce a market system, the local people end up losing out. But if the distribution of revenue is well done, the issue of inequality should not arise."

While those associated with this factor saw the potential for positive social impact from market-based conservation, respondents associated with this factor were less optimistic about the ability of markets to deliver biodiversity conservation outcomes. Like Factor Two, respondents linked to Factor Three strongly agreed that "there is a risk that in a market, artificial substitutes may become more competitive than nature at providing services" (statement 27). Respondent 27 said, "suppose something comes along, product B, that's made very cheaply. Then the [ecosystem service] market would slump and we'd lose all traction. Markets have unpredictable slumps that are scary." Respondent 19 said, "I think markets are very risky, as we've experienced with the economic downturn. You should never rely on markets to solve the biodiversity problem."

Respondents associated with this factor seemed to be looking beyond markets for other means to conserve biodiversity. This was the only group that strongly disagreed with the idea that "market-based conservation is preferable to other forms because it is conditional on performance" (statement 6). This factor was also the only more sceptical factor with respondents who disagreed with the idea that "markets are most effective for conservation when they are directly linked to the delivery of conservation outcomes" (statement 7). These responses suggest that Factor Three respondents do not believe that market-based conservation is the most preferable or effective means of doing conservation, either despite or because of the fact that this form of conservation is sometimes linked to the delivery of conservation outcomes. Their disagreement with statements six and seven implies that this group is sceptical of the ability of markets to deliver on conservation outcomes, and believe that other methods of conservation may be more effective and better at ensuring biodiversity outcomes. Interestingly, the wariness of those associated with Factor Three about the ability of markets to deliver conservation outcomes does not come from a feeling that there needs to be more evidence, as the Factor Two perspective suggested. On the contrary, Factor Three was the only factor across both studies where respondents disagreed with the statement "we need more evidence on the impacts of market-based conservation before we go too far" (statement 24). Respondent 19 said, "we could keep going for more evidence. But in the end, we just need to do something."

Factor Three respondents did believe, alongside Factor One, that "decision makers understand monetary values, so conservation should be framed in those terms" (statement 13). This statement postulates how decision makers behave, and while respondents agreed with this description, they did not agree with this statement on normative terms or approve of its reality. Respondent 23 explained, "politicians would prefer that conservation is conveyed in messages that are easier to understand. When you convert ecosystem services into [economic] values, this tends to convey a stronger message than if you just asked them to put money into something that they don't understand." Likewise, respondent 19 said, "I agree quite strongly that decision makers understand monetary values. I don't think they know what biodiversity actually means." However, signaling their disapproval with this reality, Factor Three is the only factor in which respondents convey disagreement with the idea that conservationists should embrace market-based capitalism (statement 8).

\section{DISCUSSION}

Our comparative study found a pro-market perspective that was consistent across both study groups, and three fragmented and more critical perspectives that differed across the study groups. While some positive perspectives in each study group might have been expected given the rise of MBIs across the conservation community, the consistency of the statements that loaded onto the pro-markets Factor One across both studies is remarkable given that Q methodology is a sophisticated tool that is capable of uncovering highly detailed and nuanced subjective value positions (Watts and Stenner 2012). This result lends support to the suggestion that, although sampled in very different geographies, the individuals aligned with Factor One in both studies were in fact members of a single transnational epistemic community, with a shared way of thinking about the role of markets in conservation.

In contrast to the consistency of Factor One, the other factors we identified were distinct in character both within and across the two studies: Factor Two from the ICCB study was different in character than the Cambridge Factor Two, and the third factor that emerged from the Cambridge study offered an additional critical perspective towards the use of markets in conservation. This tension of perspectives over the use of MBIs in conservation existed not only between members of different conservation organisations, but between 
staff members within the same conservation organisation. This occurred even within organisations that have advocated and adopted market-oriented conservation activities. The lack of consistency in these factors across the two study groups suggests that the individuals aligned with these factors belong to a more fragmented discursive community, in contrast to the result for Factor One in both studies.

Why might we find a shared, supportive perspective on the role of markets in conservation among conservationists sampled at different times, on opposite sides of the globe? One possibility is that those holding these views have been exposed to a consistent and influential set of global communications that have promoted this view, such as the 2010 'The Economics of Ecosystems and Biodiversity' (TEEB) study (TEEB 2010) or the Convention on Biological Diversity's 'Strategic Plan for Biodiversity' 2011-2020 (CBD 2010). To our knowledge, no equivalent critical communication on the role of markets in conservation have been as influential, or similarly promoted amongst conservationists.

A second possibility is that some of the individuals we sampled actively participate in transnational networks and events within which such ideas are created and circulated. ${ }^{8}$ Participants in such networks might be expected to be more senior within their organisations, as it is usually senior staff who attend the conferences and conventions central to the operations of such networks (Büscher 2014; Campbell 2010; Campbell et al. 2014; MacDonald 2010a). To investigate this possibility within our own data, we examined the relationship between each respondent's relative seniority within their conservation organisation, the relative size of their organisation, and their association with each factor. One pattern that emerged was that senior-level respondents from large, internationally focused conservation organisations were associated with the pro-market Factor One (see Table 2). Likewise, respondents who loaded onto the more sceptical factors in both studies tended to hold mid-level positions or work for smaller, national or more locally focused conservation organisations. This pattern was apparent even amongst employees of the same conservation organisations within our sample.

Given the scope of this study, we acknowledge that we are unable to say whether this retrospective observation on seniority exists outside of our sample. In particular, the Q methodology study design does not allow inferential conclusions to be drawn, regarding for instance the relationship between association with factors and the demographic characteristics of the sample. However, these initial empirical data do provide some support for Holmes' (2011) proposed epistemic community — a 'transnational policy elite' — promoting 'fast' neoliberal conservation policy (after Peck and Theodore $2010 \mathrm{~b}$ ). The expression of a nearly identical perspective about market-based approaches in conservation across individuals in senior positions within two distinct conservation networks suggests that there is a consistent and apparently durable pro-market perspective that exists and persists amongst elite conservation professionals from different geographies. This might be sharpened into 'alignment' (Peck and Theodore
Table 2

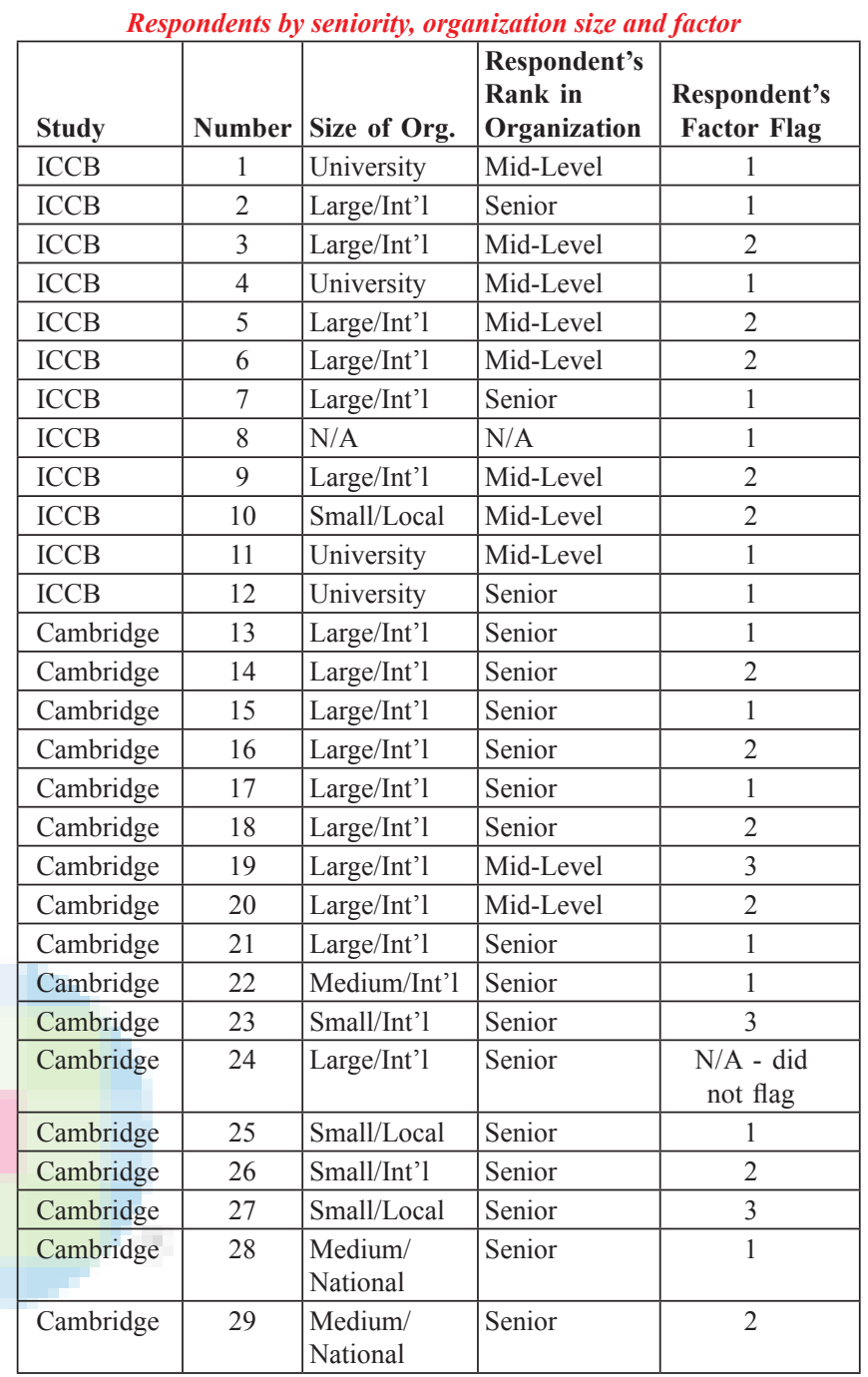

2010a; Wenger 2000) at various points of overlap within the conservation community's transnational policy networks, and at events such as international conferences where such transnational elites come together (MacDonald 2010a).

In contrast to Factor One, the more sceptical perspectives found in Factor Two of the ICCB study, and the distinct Factors Two and Three from the Cambridge study, were non-uniform and lacked the alignment seen in the pro-market Factor One. This points to the fragmented nature of dissent within the conservation community amongst those who are more sceptical towards the dominant thinking about neoliberal conservation. These more sceptical factors, primarily voiced in our small and non-representative sample by mid-level conservation professionals and those in smaller, nationally or regionally focused conservation organisations, provide some empirical flesh to the suggested fractured nature of less dominant ideas, which lack the alignment of an actively promoted perspective.

Further, in examining the perspectives represented by these less dominant factors, it should be noted that each sceptical factor was sceptical primarily on the grounds of inconclusive 
evidence (Cambridge Factor Two), on-the-ground pragmatism (Cambridge Factor Three), or cautious pragmatism merged with a scepticism about whether markets are too unpredictable and problematic to be applied to conservation (ICCB Factor Two). In other words, despite being more wary of market-based approaches, all the more sceptical factors represented viewpoints of support for the deployment of market-based policy under certain conditions. Thus, even within the sceptical factors across both studies, we found no factor representing a critique that comes close to the perspective of critical social scientists studying the use of MBIs, despite the Cambridge respondents being part of a geographically co-located conservation network that includes such critical scholars. Indeed, the lack of familiarity with the term 'neoliberalism' amongst all participants corroborates this point. It would be very interesting to conduct similar research among the epistemic community of critical social science scholars writing about neoliberal conservation to establish whether a globally shared critical perspective on the role of markets in conservation exists among them, along the same lines as the consistent Factor One we identified among conservationists. ${ }^{9}$

The absence of strongly critical viewpoints among the conservationists in our study groups could be the outcome of what Büscher et al (2012) have called the 'disciplining of dissent' within neoliberal conservation ideology. This could happen in two ways. First, despite the study participants being asked to express their personal viewpoints, they may have been reluctant to express critical views that are counter to the pro-market perspective that has so much momentum. Second, people with critical views may be absent from mainstream conservation research and practice organisations because they are not hired in the first place.

\section{CONCLUSION}

This comparative study identified a strikingly consistent pro-market perspective surrounding the use of MBIs in conservation amongst two groups of conservation professionals, in two different contexts where conservation professionals convene. The similarity of this particular promarket perspective corroborated the observation that the adoption of a particular neoliberal, market-led approach to conservation exists and persists within the broader biodiversity conservation community. Our evidence also supports a growing body of research that suggests that pro-market and neoliberal approaches to conservation are embedded within the thought processes of some decision makers and staff of conservation organisations. This finding also lends some support to the proposed existence of a transnational conservation elite (Holmes 2011) that supports these developments. Second, this research corroborates earlier findings that pro-market perspectives in conservation are not altogether uncontested. Our comparative results show that the consistency of pro-market perspectives was matched by fragmented sceptical perspectives among other conservation professionals. The additional critical perspectives that emerged in the Cambridge study corroborates the ICCB study's findings that there is some tension in the way that conservationists think about markets (Sandbrook et al. 2013b), and a plurality of perspectives in the ways that conservationists value nature (Sandbrook et al. 2011).

Q methodology offers the ability to quantitatively study subjectivity, allowing detailed comparison of perspectives. While taking a comparative approach to Q studies is relatively new, this approach allows for further exploration into the perspectives of conservation actors and professionals across different conservation organisations and networks. This study, and future studies in this area, could be supplemented by other Q study designs, similar to that followed by Rastogi et al (2013) that use online surveys to measure the popular approval of viewpoints identified by Q. Further research could continue to explore the indications we have reported regarding influence of seniority and the extent to which leaders within large, internationally focused conservation organisations circulate pro-market perspectives.

\section{ACKNOWLEDGMENTS}

We thank the staff of various conservation organisations in Cambridge, UK for participating in the Q survey interviews for this study, and the Gates Cambridge Trust for supporting the first author's research. We also thank the three anonymous reviewers of this paper for their insightful comments, which have considerably sharpened our argument.

\section{NOTES}

1. Cambridge Conservation Initiative: Transforming the landscape of biodiversity conservation. http://www.conservation.cam. ac.uk/. Accessed on February 12, 2014.

2. Cambridge Conservation Forum. http://www. cambridgeconservationforum.org.uk/. Accessed on February 12, 2014.

3. Cambridge Conservation Initiative: Transforming the landscape of biodiversity conservation. http://www.conservation.cam. ac.uk/. Accessed on February 12, 2014.

4. University of Cambridge Conservation Research Institute. http://research-institute.conservation.cam.ac.uk/. Accessed on February 12, 2014.

5. While we thought that all the statements would be familiar, given Sandbrook el al's 2013 testing of the Q sort in the original study, we actually found this not to be the case. One statement, which focused on the term 'neoliberalism' was unfamiliar to the Cambridge study participants. Indeed, this was a discovery of an ill-designed study question that ended up soliciting a response that was illuminating (see our discussion in the results of the paper on this).

6. Although the term 'neoliberal' is not commonly invoked in biodiversity conservation conferences or email lists, promoters of market based conservation "effectively associate the central elements of neoliberal conservation without using a single 
related word" (Igoe and Brockington 2007: 435). Büscher and Dressler (2007) call this a 'discursive blur.'

7. Note that all respondents from each study were given a unique number, as seen in Table 2, so as to not confuse respondents across both studies. Respondents 1-12 are from the ICCB study, while respondents 13-29 are from the Cambridge study.

8. Such network events include the IUCN's World Conservation Congress and the Society for Conservation Biology meetings (see MacDonald 2010a).

9. Such research could potentially be conducted at critical social science events such as "Grabbing Green" or the "STEPS: Resource Politics” conferences.

\section{REFERENCES}

Arsel, M. and B. Büscher. 2012. Nature ${ }^{\mathrm{TM}}$ Inc.: Changes and Continuities in Neoliberal Conservation and Market-based Environmental Policy. Development and Change 43: 53-78.

Balmford, A. and T. Whitten. 2003. Who should pay for tropical conservation, and how could the costs be met? Oryx 37(2): 238-250.

Brannstrom, C. 2011. A Q-Method Analysis of Environmental Governance Discourses in Brazil's Northeastern Soy Frontier. The Professional Geographer 63: 531-549.

Brockington, D. 2002. Fortress Conservation: the preservation of the Mkomazi Game Reserve, Tanzania. Oxford: International African Institute.

Brockington, D. and R. Duffy. 2011. Capitalism and Conservation. Chichester: Wiley Blackwell.

Brown, S. 1980. Political Subjectivity: applications of Q Methodology in Political Science. New Haven: Yale University Press.

Büscher, B. 2014. Collaborative Event Ethnography: between structural power and empirical nuance? Global Environmental Politics 14(3): 132-138.

Büscher, B.and W. Dressler. 2007. Linking Neoprotectionism and Environmental Governance: on the rapidly increasing tensions between actors in the environment-development nexus. Conservation and Society 5(4): 586-611.

Büscher, B., S. Sullivan, K. Neves, J. Igoe and D. Brockington. 2012. Towards a synthesized critique of Neoliberal Biodiversity Conservation. Capitalism Nature Socialism 23(2): 4-30.

Campbell, L.M. 2010. Collaborative Event Ethnography: Conservation and development trade-offs at the fourth world conservation congress. Conservation and Society 8(4): 245-249.

Campbell, L.M., C. Corson, N.J. Gray, K.I. MacDonald and J.P. Brosius. 2014. Studying global environmental meetings to understand Global Environmental Governance: Collaborative Event Ethnography at the tenth conference of the parties to the Convention on Biological Diversity. Global Environmental Politics 14(3): 1-20.

Castree, N. 2008. Neoliberalising nature: the logics of deregulation and reregulation. Environment and Planning A 40: 131-152.

CBD. 2010. Strategic Plan for Biodiversity. https://www.cbd.int/sp/. Accessed on February, 2013.

Daily, G. 1997. Nature’s Services: societal dependence on natural ecosystems. Washington D.C: Island Press.

Eckert, P. 2006. Communities of Practice, In: Encyclopedia of language and linguistics. (ed. Brown, K.) $2^{\text {nd }}$ Edition.Volume 1. Pp. 683-685. London: Elsevier B.L.

Eden, S., A. Donaldson and G. Walker. 2005. Structuring subjectivities? using Q methodology in human geography. Area 37(4): 413-422.

European Commission. 2011. Our life insurance, our natural capital: an EU biodiversity strategy to 2020. http://ec.europa.eu/environment/nature/ biodiversity/comm2006/pdf/EP_resolution_april2012.pdf. Accessed on February 14, 2013.

Ferraro, P.J. 2001. Global Habitat Protection: limitations of development interventions and a role for Conservation Performance Payments. Conservation Biology 15(4): 990-1000.

Haas, P.M. 1992. Introduction: epistemic communities and international policy coordination. International Organization 46(01): 1.

Harvey, D. 2003. The New Imperialism. Oxford: Oxford University Press.

Harvey, D. 2006. Spaces of global capitalism: towards a theory of uneven geographical development. London:Verso.

Heynen, N. and P. Robbins. 2005. The neoliberalization of nature: governance, privatization, enclosure and valuation. Capitalism Nature Socialism 16(1): 5-8

Holmes, G. 2011. Conservation's friends in high places: neoliberalism, networks, and the Transnational Conservation Elite. Global Environmental Politics 11(4): 1-21.

Igoe, J. and D. Brockington. 2007. Neoliberal Conservation: a brief introduction. Conservation and Society 5(4): 432-449.

Landell-Mills, N. and I.T Porras. 2002. Silver bullet or fools' gold? a global review of markets for forest environmental services and their impact on the poor. Instruments for sustainable private sector foresty series. International Institute for Environment and Development, London.

Lave, J. and E.Wenger. 1991. Situated Learning: Legitimate Peripheral Participation. Cambridge: Cambridge University Press.

López-i-Gelats, F., J.D Tàbara and J. Bartolomé. 2009. The rural in dispute: discourses of rurality in the Pyrenees. Geoforum 40(4): 602-612.

MacDonald, K. 2010a. Business, biodiversity and new 'fields' of conservation: the world conservation congress and the renegotiation of organisational order. Conservation and Society 8 (4): 268.

MacDonald, K.I. 2010b. The devil is in the (bio)diversity: private sector "engagement" and the restructuring of biodiversity conservation. Antipode 42 (3): 513-550.

Mazur, K.E. and S.T. Asah. 2013. Clarifying standpoints in the gray wolf recovery conflict: procuring management and policy forethought. Biological Conservation 167: 79-89.

McAfee, K. 2012. The Contradictory Logic of Global Ecosystem Services Markets. Development and Change 43 (1): 105-131.

McCarthy, J. and S. Prudham. 2004. Neoliberal nature and the nature of neoliberalism. Geoforum 35(3): 275-283.

Muradian, R., M. Arsel, L.Pellegrini, F. Adaman, B. Aguilar, B. Agarwal, E. Corbera et al. 2013. Payments for ecosystem services and the fatal attraction of win-win solutions. Conservation Letters 6 (4): 274-279.

Pagiola, S., A. Arcenas and G. Platais. 2005. Can payments for environmental services help reduce poverty? an exploration of the issues and the evidence to date from Latin America. World Development 33(2): 237-253.

Pattanayak, S.K., S.Wunder and P.J .Ferraro. 2010. Show me the money: do payments supply environmental services in developing countries? Review of Environmental Economics and Policy 4 (2): 254-274.

Pearce, D.W. and E. Barbier. 2000. Blueprint for a sustainable economy. London: Earthscan.

Peck, J. 2011. Global policy models, globalizing poverty management: international convergence or fast-policy integration? Geography Compass 5(4): 165-181.

Peck, J. and N. Theodore. 2010a. Mobilizing policy: models, methods, and mutations. Geoforum 41(2): 169-174.

Peck, J. and N. Theodore. 2010b. Recombinant workfare, across the Americas: transnationalizing "fast" social policy. Geoforum 41 (2): 195-208.

Pirard, R. 2012. Market-based instruments for biodiversity and ecosystem services: a lexicon. Environmental Science \& Policy 19-20: 59-68.

Rastogi, A., G.M Hickey, R. Badola and S.A Hussain. 2013. Diverging viewpoints on tiger conservation: a Q-method study and survey of conservation professionals in India. Biological Conservation 161: 182-192.

Robbins, P. 2000. The Practical politics of knowing: State Environmental 


\section{4 / Blanchard et al.}

Knowledge and Local Political Economy. Economic Geography 76 (2): 126-144.

Robbins, P. 2006. The politics of barstool biology: environmental knowledge and power in greater Northern Yellowstone. Geoforum 37 (2): 185-199.

Sandbrook, C., W.M. Adams, B. Büscher and B.Vira. 2013a. Social Research and Biodiversity Conservation. Conservation Biology: 1-4.

Sandbrook, C., I.R Scales, B.Vira and W.M Adams. 2011. Value plurality among conservation professionals. Conservation Biology 25 (2): 285-294.

Sandbrook, C.G., J.A Fisher and B.Vira. 2013b. What do conservationists think about markets? Geoforum 50: 232-240.

Sandel, M.. 2012. What money can't buy: the moral limits of markets. London: Penguin Books.

Schurman, R.A and D.T Kelso. 2003. Engineering trouble: biotechnology and its discontents. Berkeley: University of California Press.

Stokstad, E. 2016. Conservation researchers get a new roost in Cambridge. Science 351(6269): 114.

Storm, S. 2009. Capitalism and climate change: can the invisible hand adjust the natural thermostat? Development and Change 40 (6): 1011-1038.

TEEB. 2010. Mainstreaming the economics of nature: a synthesis of the approach, conclusions and recommendations of TEEB. http://www. teebweb.org/our-publications/teeb-study-reports/synthesis-report/ . Accessed on February 20, 2013.

Tuler, S. and T. Webler. 2009. Stakeholder perspectives about marine oil spill response objectives: a comparative Q study of four regions. Journal of Contingencies and Crisis Management 17(2): 95-107.

UNEP. 2011. Towards a green economy: Pathways to sustainable development and poverty eradication. $\mathrm{http} / / / \mathrm{www} . u n e p . o r g /$ greeneconomy. Accessed on January 13, 2013.

Vira, B. 2002. Trading with the enemy? examining north-south perspectives in the climate change debate, In: Economics, Ethics, and Environmental Policy. (eds. Bromley, D.W. and J.Paavola). Pp. 164-180. Oxford: Blackwell Publishing.

Vira, B. 2015. Taking natural limits seriously: implications for development studies and the environment. Development and Change 46(4) : 762-776.

Watts, S.and P. Stenner. 2012. Doing Q methodological research: theory, mind and interpretation. London: Sage Publications.

Wenger, E. 2000. Communities of practice and social learning systems. Organization Articles 7(2): 225-246.

Wunder, S. 2007. The efficiency of payments for environmental services in tropical conservation. Conservation Biology 21(1): 48-58.

Received: May 2015; Accepted: February 2016

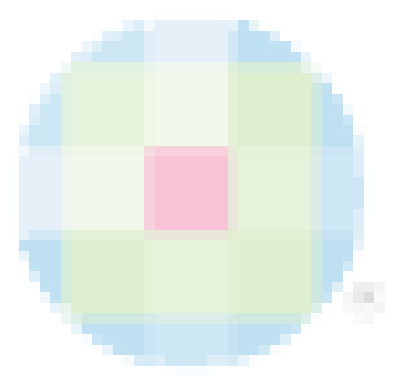

